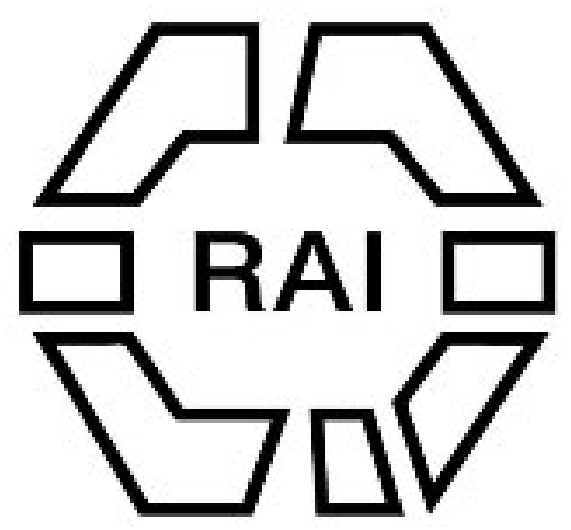

On the Age of the Hyaena-Bed at the Victoria Cave, Settle, and Its Bearing on the Antiquity of Man.

Author(s): R. H. Tiddeman

Source: The Journal of the Anthropological Institute of Great Britain and Ireland, Vol. 7 (1878), pp. 165-185

Published by: Royal Anthropological Institute of Great Britain and Ireland

Stable URL: http://www.jstor.org/stable/2841385

Accessed: $16 / 06 / 2014$ 17:13

Your use of the JSTOR archive indicates your acceptance of the Terms \& Conditions of Use, available at http://www.jstor.org/page/info/about/policies/terms.jsp

JSTOR is a not-for-profit service that helps scholars, researchers, and students discover, use, and build upon a wide range of content in a trusted digital archive. We use information technology and tools to increase productivity and facilitate new forms of scholarship. For more information about JSTOR, please contact support@jstor.org.

Royal Anthropological Institute of Great Britain and Ireland is collaborating with JSTOR to digitize, preserve and extend access to The Journal of the Anthropological Institute of Great Britain and Ireland. 
which forms the lining of the troughs and hollows in the Beeches Pit. It seems to be an old deposit, in the upper part of what is now a dry valley, which has been scooped out tlirough a great mass of loam, boulder-clay, \&c. (B), which had partly filled it. Implements are said to have been found also in the south corner of the same pit where the beds are let down in pipes, and somewhat contorted. Such contortions are often due to the removal of part of the calcareous matter of the chalky gravel or loam or the underlying chalk itself, and the consequent dropping in of the earthy residue and overlying beds. Some of the curves are apparent, not real contortions, being due to the alteration of colour by infiltering water. But this section is not clear.

On the whole, the evidence goes to show that from the first emergence of land out of the glacial sea, sub-aërial and aqueous denudation have been working at it and cutting it down often along the lines of old pre-glacial valleys, leaving a river terrace here, a mass of rainwash or other talus there; estuarine silt in one place, pond-mud in another, and that man appeared on the scene early in this post-glacial period.

Before that emergence, icebergs and coast-ice carried their load south, and dropped it in the sea (witness the boulderclays with shells or shore shingle or beds of sand). Sometimes the ice grounded (witness the great furrows and the contortions). Sometimes the sea sifted the material (witness the sorted and stratified gravel, and sand, and loam, and clay). Sometimes the ice dropped it as it got it (witness the boulder-clay with moraine-like masses). Even in the midst of such unfavourable conditions man may have been a not unfrequent visitor, as now, along the shores of arctic seas, but as a matter of fact, there is as yet no evidence that man was there.

\section{On the Age of the Hyana-Bed at the Victoria Cave, Settle, and its bearing on the ANTIQUITY OF MAN. By $\mathrm{R} . \mathrm{H}$. Tiddeman, M.A., F.G.S., of H.M. Geological Survey.}

IT was lately remarked in a discussion at the Geological Society, arising upon Messrs. Mello and Dawkins' papers, on the Creswell Crag Caves, that the "whole matter" of the antiquity of man, so far as the the Victoria Cave bore evidence, resolved itself into a very small point. The speaker, Dr. Murie, went on to state, that " he had examined a certain bone from the cave, hitherto supposed to be a human fibula, and in his opinion it might be almost any bone, and that all ideas of the habits of the VOL. VII. 
cave-dwellers founded upon it were therefore mere fictions." This second remark may be considered superfluous, for no such ideas founded upon it have, I believe, made their way into any scientific works or periodicals. Without at all calling in question Dr. Murie's skill and judgment, we may remark that the latest expressed opinion is not, ipso facto, the most correct, and it will remain to be seen whether it will have greater weight than the previously expressed opinions to the contrary, by Professor Busk, Mr. James Flower, Professor Rupert Jones, and others.

Be this as it may, the chief value of the Victoria Cave lies in the opportunity which it gives of correlating the ancient faunas contained in it, and which are elsewhere associated with the bones or handiwork of man, with certain great events in geological time. But supposing that the fibula cannot be regarded as a certain proof of man's presence in that district at the time when the hyæna-bed was being formed, we have not yet come to the end of the evidence bearing on this particular point; objects bearing marks made by man are as good proofs of man's presence as his own bones.

On the 10th of June, 1875, when the Rev. Mr. Crosskey and I were at the cave, a small bone turned up bearing upon it marks which cannot be considered to have been made by other than human agency. It lay in 2-foot parallel 1, under the datumline, from which the position of the "finds" is measured, and at a depth in the deposits of 25 feet from the original surface.* It is about $2 \frac{1}{2}$ inches of the dorsal end of a rib, but the articulating surfaces are broken off. There are at least nine transverse nicks, with others less distinct, joining them obliquely, and one longitudinal nick near the head. They appear to have been made by some clumsy instrument drawn backwards and forwards. They are quite unlike the gnawings of either rodents or carnivores. Professor Busk considers the bone to belong to a small ruminant.

About eleven months later, on the 2nd of May, 1876, another bone, a small humerus, $\dagger$ was found bearing very evident toolmarks. It occurred in parallel 17, at 17 feet right of the datumline, at a depth of 15 feet. The marks are very clean cuts as if made by a sharp instrument, so sharp indeed as almost to suggest that they may have been done with a metallic tool. The cuts however are evidently not made subsequently to the discovery of the bone, for the surfaces therein exposed are of the same colour and have the same dark and ochreous staining and incrustation as the general surface of the bone. Its occurrence,

* Its register number is $\frac{2}{135}$.

+ Register number $\frac{3}{90}$. 
however, at the depth of 15 feet, in the hyæna-bed, and surrounded by bones and teeth of hyæna, bear, elephant, and rhinoceros, precludes us from assigning to it a modern origin in spite of the sharp nature of the cuts. It may be a question whether a sharp flint flake properly hafted may not be capable of producing in a bone of a freshly-slaughtered animal marks similar to these. In the absence of Professor Busk, I forwarded it to Mr. William Davies, of the British Museum, and he says the humerus " is that of a very small goat, but evidently of an adult. It is smaller than the humerus of a true Shetland sheep with which I compared it, and besides the narrower fossa which you refer to, there are other points in which it differs from the same bone in the sheep." Mr. Davies goes on to remark upon the good preservation of the bone, which leads him to think it must be of comparatively recent age. This, however, is a common condition in bones from the hyæna-layer.

On this point it may be well to remark that no fact has been more strongly brought out by the exploration, than that the condition of a bone is no test of its age; coeteris paribus, of course, a newer bone will be fresher than an older, but the nature of the matrix in which a bone is buried has a far greater influence over its destruction or preservation than the mere lapse of time; for this reason, that it may either, if permeable, expose it to destructive influences, or, on the other hand, if impermeable, entirely arrest decay. The bones of the Roman layer in the loose débris outside the cave are in a far worse condition than the greater part of the much older remains in the stiff clay of the hyænabed. Many bones from the stiff clays of the lias and oolites are better preserved than the bones of sheep which have been bleaching on the moors during the brief space of our own lifetime. These remarks are strikingly exemplified by different portions of a pair of reindeer antlers found scattered about the upper beds in the cave; some portions which had been exposed on the surface or imbedded in lighter material, had lost their outer coating and were very friable, whilst other fragments from a stiff clay were in good condition. To have assumed that their portions were of different ages would have been wholly wrong, and the fitting together of them undeniably proved it.*

There is perhaps another objection which should be considered. It is commonly supposed that goats, with some other domesticated breeds, had not found their way into Britain during pleistocene times, and that they were subsequently imported for the first time by neolithic herdsmen. $A$ prior $i$, it does not seem impossible for goats to exist and even flourish outside the pale p. 197.

* See also “L'Homme pendant les Ages de la Pierre." Par M. E. Dupont, 
of civilisation. There can, I think, be scarcely any doubt that in the Victoria Cave remains of goat are not uncommon in the hyæna-bed associated with elephant, rhinoceros, hippopotamus, \&c. The same fact has been observed by M. E. Dupont in many of the Belgian bone-caves.* It seems therefore at least unreasonable to suppose that the goat was living on the continent in pleistocene times, with this ancient fauna, and yet did not accompany them to this part of the then continent, when they overspread it. Putting all these circumstances together, and regarding them as impartially as possible, it is by no means easy to escape the conclusion that we have in the Victoria Cave evidence of man's co-existence in the North of Fngland with the ancient fauna already mentioned. This is a fact which the cave holds only in common with other caves, and in itself would be of comparatively little importance, did not the possibility arise of correlating the existence of these early congeners of man with the occurrence of widespread physical changes.

It is my intention now to treat of this question. In doing so I shall confine myself to the broad outlines of geological knowledge bearing on the matter. It would be out of place to bring before this Society the minuter details, ascertained in the excavation of the cave and carefully noted from time to time. These have already appeared in summary in the British Association Reports, and prove without room for doubt that the hyæna-bed in the cave has glacial deposits resting upon it, and therefore is in a sense pre-glacial. Ingenious speculations have been brought forwarded by Professor T. McK. Hughes and others to show that under certain circumstances it is just possible that these glacial beds were not deposited where they have been found by glacial action; but none of these suggestions tally with all the facts recorded, and in seeking to lay what is a difficulty to some minds, they really raise others which are greater.

The older bone-bed, or hyæna-bed, in the Victoria Cave, contains amongst others, beside hyæna, thefollowing, Elephas antiquus, Rhinoceros, leptorhinus, hippopotamus. $†$ These constitute a wellmarked fauna, about which no doubt is entertained by geologists that they are contemporary. They are found in old river-gravels, in France, in Switzerland, and in the South and East of England,

* See also "L'Homme pendant les Ages de la Pierre." Par M. E. Dupont, passim. In a letter to the author, bearing date August 24, 1877, M. Dupont writes: "La chèvre de nos cavernes ne peut être distinguée de la chèvre ordinaire. Elle y est associée au Mammouth, au Rhinocéros tichorhinus, à l'Ursus spelaus, etc. J'en maintiens absolument la co-existence avec ces espèces perdues. Ces observations corroborent donc la vôtre, et je ne doute pas qu'elles ne soient constamment confirmées à l'avenir."

† The remaining species are not so accurately determinable, or, occurring as they do above as well as below the glacial drifts of the North-West of England, give no definite indications of time, and therefore cannot assist us in this inquiry. 
and in each of these countries are associated with the remains of man or his works. In Belgium they occur in caves similarly associated.

The geologists who have worked chiefly in the South of England, and studied the superficial deposits there, maintain as a body, and I think rightly, that these remains are there postglacial. But some go further, and do wrongly in assuming because they are post-glacial in the South of England, they must be so in the North. At first sight this appears almost an axiom, but further study will show that it is a great error, and I believe it is to this apparent discrepancy between the age of these deposits in the North and South of England, that much of the scepticism which has prevailed as to the pre- or inter-glacial age of man is owing. I must, therefore, beg permission to examine this matter, for there is really no need for such great differences between the opinions of the geologists of the South of England and those of the North. In the North our opinion that these animals are pre-glacial subjects us to the accusation of putting the cart before the horse. We may accept the metaphor and justify the deed. Horses usually in the South of England are put before the cart, and were I to say that in the North I have seen the horses harnessed to the backs of the carts, my statement would probably be received by some with derisive incredulity. The fact is none the less true, and when I state that in these cases there is a horse also in the shafts in front, the difficulty vanishes and the fact may be admitted. We have perhaps in the North drawn more attention to the horse behind the cart than to that in front, because its position is not so generally recognised. At the same time, we admit most fully that the shaft-horse of the South is an admirable and necessary institution, which we cannot dispense with in the North, though we reserve to ourselves the right to retain a horse also behind the cart (as a drag) when the steeper gradients of our hills and dales render its assistance indispensable.

To drop metaphor, we may admit that man as a contemporary of this particular fauna is in the South and East of England post-glacial, whereas in the North-West he is pre-glacial, and yet there is no contradiction in these two statements. We have, in short, evidence of two strongly-marked glacial periods, of which the earlier left its traces far down into the South of England, whereas the latter did not extend its icy fingers further south than the Midland Counties, probably not so far.* This is by no

* Mr. Searles Wood, junior, I believe, first expressed an opinion that the drifts of Scotland and the North of England were of later age than those of the Eastern Counties, but on somewhat different grounds. See Geological Magazine, vol. ix, p. 171, 1872 , 
means an easy thing to prove, for glacial deposits of one age are very similar to those of another; yet there is, I think, a clue to the difficulty.

In 1871 I had the honour of reading a paper to the Geological Society of London, in which I endeavoured to prove the former existence of a wide-spread ice-sheet in the North-West of England.* The conclusion that I came to from the evidence which I had been collecting for some years, was that nearly the whole of that region south of the Lake District and west of the Pennine Chain had been covered with an extensive ice-sheet which had worked over the country in the main southward. The direction of the travelling of such a sheet was shown by the scratches on the rocks and the movements of materials, which appeared to have a general trend irrespective of all but the greatest physical features of the district.

The valuable papers of my colleagues, Mr. Dakyns, $\uparrow$ which appeared at the same time, and Messrs. Ward, + and Goodchild,\$ which came out subsequently, have demonstrated a similar state of things in the districts to the East, North, and North-East respectively, and further to the south the conclusions have been supported in the main by Professor Ramsay,\| Messrs. John Aitken, 9 and Thomas Tate, ${ }^{* *}$ and have received the assent of most geologists.

If any be sceptical of these conclusions, let them at least consider what would be the effect of such a sheet of ice of the great thickness which it must necessarily have been, moving over the ground slowly but irresistibly. All previous surfaceaccumulations, such as soil, screes, or talus, older glacial drifts, and river-gravels would be removed from their position, ground up and worked up into glacial drift. The greater part of this would be carried long distances in the direction of the ice-flow. On a change from a cold to a more genial climate, as the ice

* " On the Evidence for the Ice-Sheet in North Lancashire and adjacent parts of Yorkshire and Westmoreland." Quarterly Journal Geological Society, vol. xxviii, p. 471-191, 1872.

† "The Glacial Phenomena of the Yorkshire Uplands." Quarterly Journal Geological Society, vol. xxviii, p. 384, 1872.

¥ "The Glaciation of the Northern part of the Lake District." Ibid., rol. xxix, p. 422, 1873.

§ "The Glacial Phenomena of the Eden Valley and the Western part of the Yorkshire Dale District." Ibid., vol. xxxi, p. 55, 1875.

|| "Physical Geology and Geography of Great Britain." Third Edition, p. 161, 1872. Also, "How Anglesey became an Island." Quarterly Journal Geological Society, vol. xxxii, p. 119, 1876.

T "On the Unequal Distribution of Drift on opposite sides of the Pennine Chain." Ibid., vol. xxxii, p. 184, 1876.

** "The Glacial Deposits of the Bradford Basin." Proceedings Geological and Polytechnic Society of the West Riding of Yorkshire; New Series, part ii, p. 101. 
slowly receded, it would leave the solid rocks bare of all previous drifts, covered only by the mud and boulders and rubbish melting out of it, which itself had made, and the coarse gravels formed by the streams flowing out of the ends of the glaciers in their slow retreat. And in thus losing all earlier surface-accumulations, we should also certainly lose all traces in the open country of all its former inhabitants, whether man or beast.* Flint implements would disappear, if they had existed, equally with the less durable remains of man. Only in the shelter of caves or rock fissures would there be a chance of any traces of the older inhabitants remaining. And just this state of things which should result if an ice-sheet had passed over a portion of the country, is precisely what we do find in the North-West of England.

Professor Boyd Dawkins, I believe, first called attention to the fact that those areas in Great Britain in which the marks of glaciers were the freshest and most abundant, coincided with those which were barren of the remains of the pleistocene mammalia, and inferred in the then state of our knowledge that the areas in question were covered by ice at the time that pleistocene animals were so numerous in the caves and river deposits of Southern and Eastern England.†

The subsequent discovery of the hyæna-bed and its contents at Settle, and still later the finding of the same fauna in an old river-gravel overlain by glacial depusits in a cave in Lothersdale near Skipton, both in well-glaciated districts, showed that these animals had existed there before the last great glaciation. Had they existed in that country after it, we could not fail to have found their remains somewhere in the river-gravels of that district, which must have been at one time as fully occupied by them as the South of England, where they are now found so abundantly in the river-gravels. +

Our ice-sheet of the Northern Counties could not spread south for ever, and must have had a limit somewhere, and we find evidence of that limit in districts which bear no distinct traces of glaciation. The high country of the peak and the Mountain Limestone of Derbyshire is free from those extensive sheets of glacial rubbish which occupy the country to the east, west, and north, of it as may be seen in the valuable drift-map by Professor A. H. Green, in the Geological Survey Memoir on that

* First suggested by Professor T. F. Jamieson, on à priori grounds, in, I think, his paper, "History of the Last Geological Changes in Scotland." Quarterly Journal Geological Society, vol. xxi, pp. 161-203, 1866.

† "Popular Science Review," October, 1871.

\$ See remarks on this by the author, "Geological Magazine," vol, x, p. 11 ; ibid., p. 140; "Nature," vol. ix, No. 210, p. 14, 
county.* The outlying patches of drift which do occur in it are probably the worn remnants of an old and earlier glaciation.

It seems likely that this district, and some other patches of high ground a little further north, were like the so-called islands forming the coast of Greenland, described by Dr. Robert Brown in his invaluable paper. $\uparrow$ These are only insulated by the ice and separated from each other by the great broad tongues of ice which drain the universal sheet of the interior. He likens Greenland and its interior ice-field to a broad-lipped shallow vessel with chinks in the lips here and there, and the glaciers, like viscous matter, pouring out through them, the broad lips being the "islands."

The ice-sheet must have been melting away and thinning away considerably when at its maximum both to the west and east of the Derbyshire hills, and there is nothing unreasonable in supposing that such high ground may have been comparatively free from ice, whilst its sides were hugged by the broad sheet flowing from the Lake District and elsewhere, but thinning away to its final limit a little further south. Professor Dawkins' interesting discovery of rhinoceros in the screes or talus of the steep hill-sides near Castleton in the Peak District, is evidence that no ice-sheet or glacier has passed down that valley since that beast was feeding there; and in that fact the superficial deposits show their similarity to those of the south country and differ from the state of things existing in the well-glaciated region to the North. This occurrence, though at first sight exceptional, may really be regarded as a strong confirmation of this view.

To sum up, we may say that, even supposing we had never found traces of man in the Victoria Cave in the older pre-glacial beds, his great antiquity would be there fairly proved. A set of animals which are well known to have existed with man elsewhere, is there shown to have lived before an age of great land glaciation, and to have had its remains swept from that country by it. That ancient fauna lived in the South of England and the Eastern Counties upon a land-surface covered with the vestiges of a still older and more extensive glaciation, of which the traces have been swept away in the North by that later glaciation.+ This glacial period, which I consider to

* "The Geology of North Derbyshire and the adjoining Parts of Yorkshire," p. 134. See also on this subject the papers above cited, by Messrs. John Aitken and Thomas Tate.

+ "On the Physics of Arctic Ice," Quarterly Journal Geological Society, vol. xxvi, p. 677,1870 .

I It is here unnecessary to enter into the question as to how much of the East Anglian drifts are submarine or sub-aërial. It does not much affect the matter with which we have to do, and may well be left to the eminent geologists who are studying that part of the kingdom. 
have been later than man's introduction into Europe, would appear to be the same which spread the whole of Scotland and perhaps of Ireland, with a sheet or sheets of land-ice, and was succeeded in the North of England by a submergence whose utmost depth is disputed, but was not, in my opinion, greater than 400 or 500 feet.*

These views are in the main what I have held for some years. They seem to me almost entirely to reconcile the facts which have been gleaned, and to harmonise many of the discordant opinions which have been held by geologists in all parts of the kingdom. The details, of course, require filling in, but the broad views thus roughly stated may claim at least to be founded upon facts.

A letter from Mr. Whitley was read, and photographs of flint implements from Brixham Cavern were exhibited, and thanks voted to Mr. Whitley for the same.

The following letter from Dr. Nicolucci was read.

ISOLA DI LIRI, 4th May, 1877.

\section{My Dear Friend,-}

I am grieved at not yet having made any communication to you upon the men of the caverns of Italy. I can assure you that the traces of troglodyte man are not rare in Italy. They have been met with in a grotto near Torino di Sangro, in others in the Valley of the Vibrata of Viletta, Barrea and of Cappadocia, in the Abruzzi, as well as in Mount Asperano, near Roccasecca, and at Cape Leuca (Pouilles). Of all these grottos which have been inhabited in the neolithic age, I possess in my collection almost all the objects met with in stone, in bone, and pottery.

Another grotto in the Island of Palmaria (in the Gulf of Spezia, Genoa) has been explored by Capellini and Regalia, and here have been met with, among the débris of animals, fragments of human remains and object of human industry of the stone age.

The grotto of Mount Tignoro, near Livourre, has furnished to the Marquis Strozzi two crania of the polished stone period. Others have also been given to the late Regnoli from the grotto of the Chateau on the mountains of Pita, and still others have been met with by the Curate Don Perrando Deo Gratias in the cavern

* I am here referring to the "middle-sands and gravels" of Lancashire. I have for three years seen good reason for supposing that the undoubted marine deposits at much higher elevations, such as those of Moel Trefaen and Macclesfield, have really nothing to do with this, but are relics of an earlier submergence which survived the later glaciation of the North of England ice-sheet, but my reasons must be reserved for another occasion. 
of the Matti near Perti, in the territory of Savona (Liguria). All these crania have been described briefly by myself in the report already published upon the Anthropological Exposition, and of Pre-historic Archæology at the Congress of Bologna. ("L'Age de la Pierre dans les Provinces Napolitaines," Par M. Nicolucci.)

An important discovery is that which has been made by M. Issel of many skeletons in the grotto of Finale, in Liguria. These skeletons, which have unfortunately suffered many injuries in their transmission from Finale to Geneva, have not yet been studied. They are destined for the pre-historic museum at Rome, and I am engaged to go there to study them.

A complete cranium, with fragments of many others have lately come into my hands. It has been withdrawn from a grotto near Matera (Basilicata), in the same stratum which contained a great quantity of objects worked in flint, in bone, and in pottery.

If more precise descriptions of all these crania would interest the Anthropological Institute, I will endeavour to collect the different notices, and to communicate them in an express work addressed to the learned Society to which I have the honour to belong.

I do not doubt that the discussion which is to be opened on the 22nd of May, at the Anthropological Institute, upon the present state of the question of the antiquity of man, will be very important, and I shall read with the greatest interest the details of this discussion.

I have pleasure in repeating it that I am your very devoted,

\section{GIUSTINIAN NICOLUCCI.}

\section{Discussion.}

Prof. Busk wished to explain, before the discussion commenced, the circumstances connected with the interesting fragment of bone, for the determination of which he was personally responsible. This "bone of contention" was represented by the cast which he held in his hand. He was surprised that such a large superstructure had been raised upon that particular piece. It was merely a fragment, evidently of a fibula, one of the most variable bones in the body. It was received by him, together with a large collection of other remains, from Mr. Tiddeman, and for a long time remained an insoluble problem. At last, after many conjectural determinations by himself and others, Mr. James Flower, the well-known articulator to the Royal College of Surgeons, discovered in the College a human fibula of unusual size, and with which, as he pointed out, the Victoria Cave bone corresponded in many particulars. This determination, with the reasons for it, and illustrated by figures, was published in the Journal of the Institute. At the same time, Mr. Busk was per- 
fectly open to be convinced that it might be ursine. But although Prof. Boyd Dawkins had been good enough to show him bones of fossil bears of surprising size, none of them quite came up to the one in question. Nor at Toulouse, where there is such an enormous collection of ursine remains, did Mr. Busk observe any of corresponding dimensions. He was himself still disposed to regard the specimen as a fragment of an abnormally large human fibula, but thought that at present it would be unsafe to build any strong conclusions upon it.

Professor Rolleston: I have been much impressed with the liability to disturbance of the fibula. Once in digging out a British skeleton, buried in the usual contracted fashion, before coming down to the skeleton we came upon a fibula standing vertically. When we came down to the skeleton, I cleared all the stone and earth away from it, and found that the fibula in question, instead of being a bone from some previously interred and removed body, was actually one of the fibula of the skeleton lying horizontally at the bottom of the grave. Yet it is easy to see how this bone is eminently liable, as the flesh round it and the ligaments binding it decay, to be acted upon as a lever by stones settling down upon it. Then its pointed ends favour its moving. So Professor Busk, writing (Congress of Pre-Historic Archæology, 1868, p. 152) of the Genista cave at Gibraltar, says, "There were about thirty thigh bones, and eighteen to twenty tibia, but strange to say, portions of only three fibulce were observed."

As regards the judging of climate from the presence of mammals, I rather disbelieve in it. The reindeer lived in Germany in the time of Julius Cæsar, and was spoken of by him as bos cervi figura, as the Canadian reindeer is called "Carriboo" (Cerfbouf) now. The hippopotamus and rhinoceros have been supposed to indicate warmth of climate, but they appeared to me to stand the late wretched weather in the Zoological Gardens at least as well as most smaller animals. Why should they not? The power of resisting cold and generating heat depends on bulk, and bulk increases as the cube of the linear dimensions. But Schrenk, in his excellent work on "Amoorland," 1858, tells us that the tiger, an animal connected, however wrongly, with notions of tropical heat, was to be found in the island of Saghalin, which was in the cold weather connected by a bridge of ice with the mainland; and that its food there was not the buffalo nor the roe. but the reindeer. The roe was not found in Saghalin, not on account of the cold, but on account of quite another reason, the presence of pinewoods at the point of crossing from the mainland over to the island. This shows how much care is required in arguing to the presence of climatic or other inorganic condition from the presence or absence of particular animals. Reptiles are more surely indicative of temperature than most other animals; non-metabolous insects again than insects with perfect quiesence as pupce to protect them during winter, but vegetable life was a surer guide as a whole than animal. 
Professor Prestwich: You, Sir, have justly observed that to consider this question thoroughly requires the knowledge of the palæontologist, the archæologist, the anthropologist, and the geologist. I think it especially concerns the geologist in regard to the sequence of events. Palæontologists have been rather apt to overlook the geological conditions under which these specimens are found. We have to deal with the sequence of man from his first appearance in time geologically to that period when it comes within the range of ethnological inquiry. I will confine myself to the evidence in the South of England and in the North of France. In the South of England it is particularly clear and decisive. Our datum-line is positive ; it is afforded by the spread of the boulderclay, which ranges as far as south as London. That represents the glacial period. The post-glacial period I consider to be subsequent to the period of the deposit of the boulder-clay.

The first discoveries in this country were made in those districts of the South of England which had been covered over by the boulder-clay. It is in the drift and gravel of the valleys excavated in this boulder-clay that palæolithic flint implements have been so commonly found, consequently, it is clear that in all that area, man is of post-glacial age. If we get two levels, one on either side of a valley, a certain number of feet above sea-level, with masses of boulder-clay cut off on either side, then, of course, the débris at the bottom of the valley will consist of sand and gravel, derived from materials formed by the destruction of the boulder-clay and other strata which originally traversed the valley. The materials so spread out are newer than the boulder-clay, consequently, man in these valleys is post-glacial. There are sometimes as many as two or three successive levels in those valleys. If a valley excavated to a certain depth and the gravel-beds spread on that level, contain no flint implements, while at a lower and second level, flint implements are found, then we assume that man was introduced into this area only when the valley was excavated to the greater and later depth, and when the gravel was spread out on the level now occupied by our present rivers. It is interesting, therefore, to determine what may be the character of the mammalian remains of the successive terraces. Unfortunately the mammalian remains of all this period are so alike that it is impossible to determine from such evidence the age of those terraces. In the case, however, of bone-caves found on the sides of valleys and in districts where there is no boulder-clay, we are necessarily left to the palæontological evidence alone. In looking at the correlation of the deposits of the South of England, with the deposits which preceded, the glacial period in the North, there is evidence in both areas of the land having been inhabited previous to the boulder-clay period by animals which were likely to serve as the food of man. There is no à priori reason why man should not have existed before that period in the North of England; much, however, will depend upon that more complete evidence, which possibly Mr. Tiddeman may have to bring before us at some future period. 
I am disposed to consider, with $\mathrm{Mr}$. Tiddeman, that the cave which he is now investigating at Settle may be of pre-glacial age. I think it is not conclusive, but the evidence rather tends to show that it is pre-glacial. Further research may, I hope, decide on that particular point.

Taking the lower valley of the Thames, the evidence is this: We find in the valley, on terraces resting some 20, 30, or 40 feet above the present level of the Thames, palæolithic flint implements. At the Reculvers such gravels are found at an elevation of about 60 feet above the river, but as we ascend the valley we find that the evidence of the existence of man is confined to the lower levels. At Reading, in the high-level gravels on the banks of the Kennet, no flint implements have been found. Again, in the neighbourhood of Oxford, mammalian remains and flint implements are found only in the low level, and not in the higher level river-gravels.

Thus at the mouth of the Thames Valley, at the point, nearest to the coast of France, we find evidence of man's existence in the higher level older river-gravels capping the Reculver Cliffs. $\mathrm{He}$ does not then appear to have penetrated into the Upper Thames Valley. It is evident that at the period that these higher terraces were deposited in the upper part of the valley of the Thames, very cold conditions yet prevailed, though post-glacial and sulssequent to the boulder-clay. In the neighbourhood of Oxford, boulders of several tons in weight, carried down from a long distance, are found in these beds; and I have recently observed in the neighbour. hood of Reading that this gravel where it rests upon a surface which cannot be dissolved away, such as a stiff clay, in which there is no calcareous matter, presents a very peculiar eroded surface, and it fortunately happened the last time I was there, a superficies, the size of this room, was exposed, and the flat surface of the clay presented a succession of pits or hollows apparently caused by the impinging of masses of gravel-laden ice, evidently the result of mechanical force. Thus the data for carrying man back to the boulder-clay period, may be considered as an account audited and passed. But it seems to me there is also an important suspense account now accumulating. In France there is an important series of observations which have been made by competent men and good observers, and it will not do to ignore some of the points they have brought forward. I have reason to believe from my own observations in the North of France, that there is evidence of man being pre-glacial even in the North of France. There is also one specimen which I have had in my possession for many years. I can ouly answer for the locality and the condition of the bone, but not for the labelling, and from the peculiar way in which it has been cut and then broken, it certainly bears all the appearance of having been artificially worked; but I must put it to a suspense account.

One further remark I have to make. Some may think from the observations of my friend, Professor Dawkins, that the oldest flint implements we know are ruder than the later ones. Mr. Dawkins relies upon the evidence from Creswell Cave, but the cause why 
those implements are so rude is that they are made of quartzite, which cannot be finished in so neat a way as flint. In"some part of the older deposits of St. Acheul, for example, the flint implements are better made than the newer ones found in the lower gravels of the Somme Valley.

Col. Lane Fox wished to say a few words upon a point not yet touched upon in any of the papers which had been read, riz., the means by which valleys had been eroded, and the time necessary to accomplish it. The uniformitarian theory, by which it was assumed that all the work of excavating valleys had been performed by means of their rivers flowing under the same conditions as at present, had been a good deal modified of late years, and he thought he could add a few facts from personal observation tending to show that some modification of the theory was necessary. With respect to the valley of the Somme, there was evidence afforded by relics of the Roman and bronze age found in the peat in the bottom of the valley, that the river had not materially lowered its bed since those relics were deposited, and therefore it must have taken an enormous time to work out the whole valley by means of a river which flowed with the same eroding power as at present. The valley of the Somme, however, was comparatively so narrow that it was possible the whole of it might have been eroded by such means, if sufficient time were allowed. But if it could be shown that the same conditions prevailed in other very much larger valleys where the work to be done was much greater, that would afford fair presumptive evidence that the eroding force must have been greater. He could mention one or two facts which showed that the Thames like the Somme had never shifted its bed since the bronze period. The first of these was that the river some way below Oxford, at the village of Dorchester, made a great bend; the ground on one side was high, and on the other, in the space inclosed by the bend perfectly flat and low ; there was an ancient intrenchment running across this low ground from bank to bank, and converting the promontory formed by the bend of the river into a fortress. It had been ascertained by means of the relics, consisting of pottery, flints, bronze implements, \&c., associated with this intrenchment, that it was certainly as early as the bronze period, and perhaps earlier, no relic of Roman work having been found there, although Dorchester, close by, was a Roman station. The intrenchment in order to serve its purpose must have rested its flanks on the river at the time it was made, and the fact of their resting on the banks at the present time, although they are only a foot or two in height, showed that the river had not shifted or lowered its bed since the bronze age. Other evidence giving the same results was found in the same river lower down. Between Richmond and Battersea the Thames makes three or four bends in the comparatively flat bottom of the valley, which is here more than four miles wide. He had found flint implements of the drift type deposited in sedimentary sand and gravel at Acton 80 feet above the present river, the discovery of which was communicated by him to the Geological Society and 
published in their Journal. The river then since these implements were deposited must not only have lowered its bed 80 feet, but, according to the uniformitarian theory, must at each succesive level have shifted its bed repeatedly so as to work out the valley, here more than four miles wide. Yet bronze and stone implements have been found in considerable numbers in all the various bends of the present river, dredged up from the gravel at the bottom by the dredging machines that have been employed of late years, and proving that the river had neither lowered nor shifted its bed since the bronze period, but if anything it has risen since that time. Was it possible, he would submit, that at this rate of progress, if progress it could be called, the erosion of the valley could be attributed to the present river flowing under the same conditions as at present? But if, as believed by Prof. Boyd Dawkins and $\mathrm{Mr}$. Tiddeman, man existed in these parts during the subsidence of the glacial epoch, that would account, he thought, for a much greater flow of water having passed down these valleys in palæolithic times than was the case at present. In the valley of the Solent the same class of evidence was obtained. Mr. Evans had shown what a large amount of depression and erosion must have taken place in this valley since drift implements were deposited on the hill at Southampton. The valley of the Solent, from Portsdown to the Isle of Wight, is nine miles wide, and we have evidence in the Roman fortress at Porchester, how little it has changed in modern times; yet in the centre of this valley near Southsea Common, Col. Fox had some years ago discovered a flint station of the neolithic age, including celts, scrapers, and flakes in great abundance, the site of which was less than 10 feet above the present high-water mark, showing that flint implements continued to be fabricated in the valley after land and water had as. sumed its present distribution. All these facts, he thought, favoured the opinion that powerful eroding forces must have been at work before that time. The very valuable papers which had been read treated only the geological aspects of the question, but as the President had observed, there were ethnological and sociological problems to be solved, how long would it have required for the various races of man to diverge, and the earliest traces of culture to be evolved? He trusted that even if no other result came of the conference, it would show that we had not yet exhausted the subject.

The Rev. Professor SAYCE : I must begin by confessing that the evidence of language, as regards the antiquity of man, is not so decisive as that of geology. The history of language shows that his antiquity is very considerable, not that it must be measured by geological epochs. The condition of the civilised languages of the world, when we first become acquainted with them, implies a previous development of many thousands of years. It is only under certain conditions that the vocabulary of a language changes rapidly; under other conditions it changes slowly. The grammar of a language, on the other hand, may be said, roughly speaking, to 
change never, and its structure to change very rarely. If we apply these conclusions to two or three languages belonging to the principal families of speech, I think we shall arrive at the following results. Take for instance the Semitic class of languages. By means of the Assyrian monuments, we are able to get back to about 2,000 B.c. for a starting-point for these. But at that date these languages were already pretty much what they are to-day. They have changed scarcely at all in either structure, or grammar, or vocabulary. At the same time, we can see plainly enough that they pre-suppose several earlier stages of existence; and when we come to compare their grammar with that of the old Egyptian, it would seem that there was a time when the parent language of the Semitic tongues was but the sister of the parent languages of the old Egyptian. Now in order to allow for the changes that must in this case have taken place in the structare of the Semitic languages on the one side, and in that of the old Egyptian on the other side, before they become known to us, we must pre-suppose an undetermined but very great period of time.

Next, let us glance at the Aryan family. Here the different dialects can be traced back to a parent speech spoken in some part of Western Asia, probably on the table-land of the Hindu-Cush. This parent speech can be hypothetically restored by a comparison of the later languages and dialects which have descended from it. In all points of grammar and structure this parent speech was as fully developed as the Sanscrit, or Greek, or Latin of a later day. The people who spoke it were in a comparatively advanced state of civilisation, and the language itself was in a highly advanced condition. Not only had the distinction of number, gender, and case been elaborated in the noun, but the verbal conjugation, the last product of the grammatical intelligence, had been pretty fully worked out. The numerous words denoting spiritual, moral, or intellectual conceptions, which originally had a purely sensuous meaning, had already come to have their later and metaphorical sense. As soon as we analyse the grammar and vocabulary even of this ancient parent speech, it becomes quite plain that it is the last result of a long series of successive stages of growth.

Take again another language - the old agglutinative language of Babylonia. The earliest monuments that contain it must be placed between 3,000 and 2,000 B.c. On those monuments the language already appears in a state of the most utter decline and decay. And since this language was one of those literary and cultivated dialects which, as a rule, change but very slowly, we have in it evidence of an idiom which has behind it a long undetermined past. If, as several scholars believe, this language, the so-called Accadian, belongs to the Ural-Altaic family of speech, in order to get back to a period when the parent of Accadian, and the parent of the modern UralAltaic languages were one and the same, we must assume an enormous period of time.

There is another consideration connected with the evidence borne by language to the antiquity of man, which must not be overlooked. 
The science of language seems to show that most languages, whatever their present structure may be, were at one time in a condition similar to that in which the Eskimo, or North American languages, are at the present day, that is to say, a condition in which the word was not as yet distinguished from the sentence in which it was incorporated. In the case of languages so highly developed as defined, and those of the Aryan family, where the individual words are sharply marked off one from an other by grammatical suffixes, as far back as our data carry us, we must be allowed an amount of time not to be accounted by hundrcds but by thousands of years, if we are to get back to the primitive stage of polysyntheticism with which all languages, I believe, may be shown to have begun.

These, so far as I can see, would be the general conclusions to which the evidence at present furnished by the science of language as to the antiquity of man would seem to point.

Mr. T. K. CalLaRD: Do I understand that the outline of a horse represented in the diagram, belongs to the palæolithic age, and was found in the cave-earth in association with extinct animals?

Professor Dawkins : Yes.

Mr. CALLARD : We have always been led to think that palæolithic man was a rude savage who could only chip his flint implement, and knew not how to smooth it. We seem now to be getting evidence about palæolithic man of a different character. We have heard to-night of a bone needle being found in the cave-earth of Creswell caverns. A bone needle suggests to one's mind at once some step in civilisation. Men don't make bone needles unless they intend to use them, and that leads our thoughts to a palæolithic tailor, and in this very cave-earth we find evidence that artists existed at that time, and no mean artists either. Not one in three persons in this country could make a sketch like that of the horse before us. At any rate they had artists, and one thing strikes me that this Royal Academician of the palæolithic age had for his model a horse that had had his mane clipped. If so this indicates another stage of civilisation. We are very far advanced now, and it leads me to ask the question whether, finding the works of man in close proximity to the extinct mammalia, the mammoth and the woolly rhinoceros, justified us in saying that man therefore lived at a very remote period. I should be inclined to think that this does not so much prove the antiquity of man as it proves that the extinct mammalia are more modern than they are supposed to be.

The co-existence of man with the extinct mammalia tells nothing of the period of man's existence, unless it is also proven when the mammalia referred to became extinct. Of this there has been no proof adduced, and therefore to my mind the argument for man's antiquity based on the contemporaneity of man with the extinct fauna has not been sustained.

Mr. HARRISON said the palæolithic character of the flint implements found at Uissbury in connection with the remains of existing fauna, including goat and pig, showed that the form and finish of

VOL. VII, 
prehistoric tools and weapons were not of themselves a safe criterion of age. Though the earliest implements would necessarily have been the rudest, the converse was by no means true. There were doubtless art-centres in early times, as there are now, and Cissbury would not appear to have been one of them, but rather belonged to the far larger class of village manufactories. Some of the pits, he wished to say as the result of personal observation, may have been opened but a short period before our era. Their age does not directly affect the question of the antiquity of man in this country, which depends for its solution on geological facts.

The President :- I will, before calling on the authors of the papers to reply, make one or two remarks. One of the questions which have been principally discussed is this: whether in the first place we are to assign any implements found in this country to a preglacial, or inter-glacial period, or must we restrict them to a postglacial period. There is one argument which has not been insisted upon to such an extent as it may deserve. It is, that some of the implements found in the gravels in glaciated districts, are made from materials derived from glacial drift, and are therefore post. glacial. The form and character of these implements give a guide by which I think you may fairly argue that others of a similar character belong to approximately the same date. Some forms of implements are no doubt very persistent in their type, but if in a certain part of England you find implements associated with a certain fauna, and if you find them associated with the same fauna in other parts, both deposits are presumably of the same date, and if one be post-glacial, the other is also. The more we examine the theory of Mr. Dawkins, the more difficult it will be to determine from examination of the associated fauna, whether implements are pre- or post-glacial. In cave deposits, however, there are certain distinctions to be pointed out. In the cave described by Mr. Dawkins, there was a succession of beds one above the other, and I think it is in the upper beds of more recent date that relics of the primæval tailor, and the primæval artist were found. Similar relics have been found in the caves of the south of France, and a needle has been found in Kent's Carern, but at a higher level than implements which are of forms characteristic of the river-gravel. Looking at the enormous lapse of time comprised in the palæolithic period, which is evidenced by the amount of time requisite for the erosion of the river valleys, it seems possible that we shall eventually be able to establish some chronology for the palæolithic relics. If we could form any idea of the amount of time that was requisite for the excavation of a valley such as that of the Thames, we could approximately judge of the antiquity of man in this country, but for the last 2,500 years, the variation of the river-bed and its level is practically nothing, and therefore we are entirely at a loss for any measure of the power of the denuding agent, and fall back on some hypothesis as to variation in the climate. Geologists are pretty well agreed that there must have been a much greater rainfall at that period than at the present time, and the more 
constant saturation of porous rocks would, by preventing the infiltration of rain, increase the eroding power of rivers.

I have already mentioned some of the discoveries which have been made abroad, the accounts of which must be received with caution.

Some of the evidence of cut bones is, to my mind, by no means satisfactory, for I have seen what appeared to be incisions, induced by natural causes. Some here may, for instance, remember a pair of horns of the Irish elk which were embedded in each other, and were exhibited to the Geological Society.

Under certain conditions, bowes seem susceptible of receiving an impression, almost as sealing wax would from a seal.

Still, all the evidence of various classes must be collected, and it will become to a certain extent cumulative. In the case of the bones discovered by Professor Capellini, the incisions are very sharp, as if made by metal. If they were executed by metal implements, it is an argument against their antiquity, but my own impression is, that they are due to the teeth of some kind of shark. The question as to the distinction between the glacial period in the South of England and that of the North, is one of great interest. If either in the North or South we can carry back the appearance of man in this country to a time but little removed from the glacial period, we may safely infer he must have existed in other parts of Europe at a still earlier date. I will not however detain you by offering any further remarks, but will call upon the anthors of the papers for their replies.

Thanks having been voted to the authors of the papers-

Prof. Boyd Dawkins said that the first point to be considered was the antiquity of man in the Victoria Cave, based upon a small fragment of fibula, and two fragments of goat's bones which presented the appearance of having been cut. The fibula seemed to him to be ursine rather than human, and in size came within a very little (two-tenths of an inch) of the circumference of one of Ursus spelœus from Lozère. With regard to the goat's bones, he shared the opinion of Mr. Davies, of the British Museum, that they are not fossil, but recent, in other words, he did not believe that they were originally imbedded in the stratum containing the remains of the hyænas, but were derived from an upper stratum of post-Roman age in the cave, in which they are exceedingly abundant. The goat hitherto has not been found in any pleistocene strata in this country or in France, all the repeated cases of its occurrence turning out on examination to be the result of the mixing of two suites of animal remains, the one pleistocene, and the other historic or pre-historic. This is very generally done by the workmen, and this was probably the case in the Victoria Cave. But if these equivocal data be assumed to prove that man was living in this district while 
hyæ $\mathrm{ns}$ occuied the cave, the evidence is still unsatisfactory as to their pre- or post-glacial age. The hyæna stratum itself appeared to him, while the explorations were under his direction, not to be of clearly defined pre- or inter-glacial age; and his doubts as to this point were, he believed, shared by Prof. Hughes. The rudeness of the palæolithic implements in the Creswell caves from the lower strata as compared with the more highly finished ones found above them, seemed to him to imply a progress in the arts in that district. $A$ priori, the more highly finished should succeed the ruder implements, although of course many cases of their being mixed together were on record. Into the other avenues of discussion he would forbear to enter.

Professor Hughes, in reply to a question put in the course of the discussion, said he thought the evidence of antiquity upon which they could rely most was that derived from the amount of geographical change that had taken place since the deposition of beds containing remains of man. Observing the rate at which such changes take place at the present time, we must, assuming conditions to remain the same, allow a proportionately longer time for the greater changes which have taken place since the first appearance of man. But it all depended upon the assumption that conditions remain the same, as a small upheaval, for instance, would cause a rapid cutting back all along the Thames Valley and a small depression would have the contrary effect.

Referring to the remarks of Colonel Lane Fox on the age of the present channel of the Thames, he pointed out that it was probable that man had interfered more with the free course of the river during the period which has elapsed since the bronze age, than he had in all previous time, and therefore, in that case, conditions had not remained the same.

Referring to the observations of Professor Prestwich on the occurrence of pipes and pans in non-calcareous strata, he thought that they might often be explained by the settling down of stones and sand into the softened and puddled surface of the clay, the muddy water from the bottom oozing up through the stones and overflowing, and the process being repeated with greater effect each time as the pan grew deeper and the load of stones heavier. $\mathrm{He}$ thought that this was the explanation in the case adduced by Professor Prestwich, and in all such pipes in the valley brickearth.

With regard to the evidence from the gravels and clay found in caves, he had already in a paper read before the Society, brought forward evidence to prove that in the case of the Pont Newydd Cave referred to by Professor Dawkins, which contained remains of the great extinct mammals and of man, the deposits containing the fossils were certainly post-glacial. ("Journal Anthropological Institute," December 9, 1873.)

He thought that a stronger case had been made out from the evidence found in the Victoria Cave near Settle, bat even there he was convinced that the deposits containing mammalian remains 
were post-glacial. He had watched the excavations from the commencement, and was of opinion that the boulder-clay which overlapped the cave deposits had fallen from formerly-existing pits or choked swallowe-holes, such as were so common on the limestone above.

Mr. Tiddeman : As to the boulders at the cave's mouth, I thought it unnecessary to bring the question forward to-night, but as Professor Hughes has raised it, I must follow him. There is one very important point he forgot in his section of the cave. We found a mass of talus lying beneath the cliff and dipping outwards; it was 20 feet thick, and at the base of the talus we had the deposit of boulder-clay, and at the back of the boulder-clay was the hyæna-bed. Professor Hughes says this boulder-clay fell from the top of the cliff at a time subsequent to the age when the bones were deposited, and might therefore have been recent. We have above that clay 20 feet of limestone fragments weathered from the cliff above by the rain and frost of successive seasons : that represents a very considerable lapse of time since the boulders were deposited there. If the boulder-clay fell at a subsequent period, how is it that it was not mixed up with the talus? If it fell immediately after the ice melted a way and before the talus formed in any quantity, why that implies all that I maintain.

I may remark that the fibula and the cut bones are after all the smallest and most insignificant part of the evidence. The matter we have to consider is whethor that fauna which has been found in Europe and in our own isles with works of man, and in some places with his remains, lived at a time which we are able to correlate with certain great physical events. As to Pont Newydd Cave, the implements made from travelled boulders to which Professor Hughes has referred, are no evidence at all that the men who made them lived there since the last glaciation of that district. That they were made in or after glacial times does not prove that they were not prior to certain other glacial times.

With regard to a fibula making its way down into the earth, I will not dispute the fact that a bone might do that in certain cases, especially after Professor Rolleston's experience, but in the Victoria Cave it would have had great difficulty in getting down. In soft mud, it might have a chance of getting down, but if it were modern, you would have other modern things going down with it unless it had a start at the first.

Professor Rolleston: It is pointed at both ends.

Mr. TIDDEman : I do not think there could be a possibility of its working its way down. There were large blocks of stone and beds of stalagmite which we had to blast in opening the cave down to it, and it lay at a depth of 25 feet. I sincerely hope geologists will bear in mind, as new facts crop up, the suggestion that we have in England evidence of two great glacial periods, and test it by them.

The meeting then terminated. 